\title{
Teori Reduksi Ketidakpastian dalam Cyber Romantic Relationship
}

\author{
Ketut Ajeng Sespiani ${ }^{1}$, Monica Apilia ${ }^{1}$, Irwansyah ${ }^{1}$ \\ ${ }^{1}$ Program Studi Ilmu Komunikasi, Fakultas Ilmu Sosial Ilmu Politik, Universitas Indonesia \\ Jl. Salemba Raya No 4, 10430, Jakarta Pusat, DKI Jakarta, 10440, Indonesia \\ No. Telp/HP: ${ }^{1} 081238502505,{ }^{2} 082112363814$ \\ E-mail: ${ }^{1}$ ketut.ajeng@ui.ac.id, ${ }^{11}$ monica.apilia@ui.ac.id, ${ }^{1}$ irwansyah09@ui.ac.id
}

Received: Januari 2021; Accepted: April 2021; Published: Juni 2021

\begin{abstract}
The rapid development of technology and information in the digital era has an impact on the increasing use of social media which has brought significant changes to society. Social media has now been used by the community for various purposes, one of which is as a means of finding a partner or what we are familiar with as the phenomenon of online dating or cyber romantic relationships. The absence of a physical presence in cyber romantic relationships can lead to increased uncertainty. By using a qualitative descriptive approach method by collecting various previous studies, this writing was done to find out how the implementation of the uncertainty reduction theory of the cyber romantic relationship phenomenon in Indonesia. The results of this paper reveal that the relationships that exist in cyber romantic relationships tend to take place quickly from the introduction process to the commitment stage. Also, individuals communicate to reduce uncertainty. Passive and interactive strategy are always used in cyber romantic relationships.
\end{abstract}

Keywords: online dating; cyber romantic relationship; uncertainty reduction theory; qualitative; passive strategy; interactive strategy.

\begin{abstract}
Abstrak
Perkembangan teknologi dan informasi di era digital yang semakin pesat berdampak pada peningkatan penggunaan media sosial yang membawa perubahan yang signifikan pada masyarakat. Media sosial kini telah digunakan masyarakat untuk berbagai kepentingan seperti salah satunya sebagai sarana untuk mencari hingga menemukan pasangan atau yang kita kenal dengan fenomena online dating atau cyber romantic relationship. Absennya kehadiran fisik pada cyber romantic relationship dapat menyebabkan peningkatan ketidakpastian. Dengan menggunakan metode pendekatan deskriptif kualitatif dengan melakukan pengumpulan mengenai berbagai penelitian sebelumnya, penulisan ini dilakukan dengan tujuan untuk mengetahui bagaimana implementasi dari teori reduksi ketidakpastian terhadap fenomena cyber romantic relationship di Indonesia. Hasil dari penulisan ini mengungkapkan bahwa hubungan yang terjalin pada cyber romantic relationship cenderung berlangsung cepat mulai dari proses pengenalan hingga tahap berkomitmen. Selain itu, individu melakukan komunikasi untuk mengurangi ketidakpastian. Passive dan interactive strategy menjadi strategi yang selalu digunakan pada cyber romantic relationship.
\end{abstract}

Kata kunci: online dating; cyber romantic relationship; teori reduksi ketidakpastian; kualitatif; passive strategy; interactive strategy.

doi: https://doi.org/10.51544/jlmk.v5i1.1599

(C) 2021 Jurnal Lensa Mutiara Komunikasi. This is an open access article under the CC BY-SA license Website: http://e-journal.sari-mutiara.ac.id/index.php/JLMI/

http://e-journal.sari-mutiara.ac.id 


\section{PENDAHULUAN}

Dewasa ini perkembangan teknologi dan informasi di era digital semakin pesat. Salah satu halnya dapat kita lihat dengan perkembangan media sosial. Kotler \& Keller (2012), mendefinisikan media sosial sebagai sarana yang digunakan konsumen untuk melakukan aktivitas berbagi informasi berupa teks, gambar, video dan audio dengan satu sama lain ini telah menjadi suatu hal yang tidak dapat lepas dari kehidupan masyarakat khususnya di Indonesia. Di Indonesia sendiri telah terjadi peningkatan penggunaan media sosial yang cukup pesat. Hal ini dapat dilihat berdasarkan riset yang dilakukan oleh Wearesocial Hootsuite pada bulan Januari tahun 2019, pengguna media sosial di Indonesia mencapai 150 juta pengguna atau sebesar 56\% dari total populasi. Peningkatan jumlah pengguna media sosial ini salah satunya dapat disebabkan oleh kemudahan yang diberikan oleh sosial media itu sendiri. Media sosial telah mampu mewujudkan kolaborasi manusia tanpa batasan waktu dan tempat (Kamil, 2014). Selain itu, media sosial adalah mengenai menjadi manusia biasa. Manusia biasa yang saling membagi ide, bekerjasama, dan berkolaborasi untuk menciptakan kreasi, berpikir, berdebat, menemukan orang yang bisa menjadi teman baik, menemukan pasangan, dan membangun sebuah komunitas (Nasrullah, 2017).

Dalam hal menemukan pasangan tersebut, di Indonesia sendiri sudah banyak masyarakat yang menggunakan media sosial sebagai sarana untuk mencari hingga menemukan pasangan. Menurut data yang dilansir dari Vice.com, terdapat beberapa aplikasi online dating di Indonesia. Seperti, Tinder, OkCupid, Bumble, hingga Grindr. Dimana berdasarkan penelitian yang dilakukan oleh YouGov pada tahun 2019 terkait fenomena kencan di Indonesia, sebanyak sepertiga (34\%) orang Indonesia telah menggunakan internet dan aplikasi online dating. Dimana, jumlah tersebut telah mengalami peningkatan, terutama semenjak masa pandemi ini. Berdasarkan data dari Tinder yang diambil mulai tanggal 20 Februari hingga 26 Maret 2020, percakapan pengguna di Indonesia meningkat dengan rata-rata sebesar 23\%. Selain itu, rata-rata durasi percakapan meningkat $19 \%$ lebih lama. Hal yang sama juga terjadi pada data yang dilansir oleh aplikasi OkCupid yang pada aplikasinya terjadi kenaikan percakapan dan panjang waktu percakapan sebanyak 7\%. Selain itu, aplikasi online dating masuk ke dalam 10 dari 100 aplikasi terpopuler di iTunes.

Berdasarkan peningkatan jumlah pengguna seperti yang telah disampaikan di atas, beberapa aplikasi online dating tersebut melakukan inovasi dengan membuat fitur baru agar obrolan tidak membosankan. Seperti misalnya OkCupid yang kini menyediakan pilihan online dating yang dapat diisi bersama ketika dua orang sudah saling cocok. Hal ini dapat berupa mengisi playlist music bersama, menyusun daftar film yang akan ditonton bersama, dan yang lainnya. Selain itu, aplikasi Bumble juga telah menyediakan fitur yang mendorong pengguna untuk melakukan online dating yaitu dengan adanya fasilitas pengiriman rekaman suara dan video untuk pengguna yang saling cocok pada aplikasi tersebut.

Semakin berkembangnya aplikasi online dating tersebut, virtual dating menjadi salah satu fenomena / tren yang ada di masyarakat. Dimana saat masyarakat menggunakan aplikasi tersebut, tidak jarang dari mereka yang melanjutkan hubungan yang berawal dari perkenalan sebagai teman melalui aplikasi online dating berlanjut menjadi hubungan yang lebih serius. Dimana, hubungan yang lebih serius yang dijalin melalui aplikasi online dating ini sering kita kenal dengan sebutan Cyber Romantic Relationship atau CRR yang diartikan sebagai hubungan yang terjadi di internet. CRR terjadi melalui pertukaran teks digital, suara, atau melalui foto baik secara asinkronik maupun sinkronik antar individu melalui internet. 
Berdasarkan penelitian yang dilakukan oleh Fernando et al., (2020) Hal ini semakin dikuatkan dengan penelitian Fernando et al., (2020) pengguna aplikasi online dating memunculkan sebuah fenomena baru yaitu "gatsbying" di mana perempuan memiliki kecenderungan untuk menampilkan foto atau mengunggah konten sebanyak-banyaknya agar memancing perhatian laki-laki untuk menginisiasi interaksi. Dengan demikian ketika individu melakukan sedikit manipulasi, melebih-lebihkan data atau pada foto pada profil dapat mengakibatkan peningkatan ketidakpastian ketika mereka akhirnya berinteraksi dengan orang yang gagal memenuhi harapan mereka.

Ketika muncul ketidakpastian pada tahap awal interaksi suatu hubungan karena perbedaan perspektif, seseorang memiliki kecenderungan untuk mencari informasi calon pasangannya untuk mengurangi ketidakpastian. Teori reduksi ketidakpastian diperkenalkan oleh Berger \& Calabrese pada tahun 1975. Menurut Berger, seseorang akan mencari informasi mengenai realitas sosial, biasanya individu akan melakukan beragam taktik untuk mengurangi ketidakpastian ini. Walaupun tujuan komunikasinya berbeda namun secara garis besar dapat dikategorikan menjadi tiga strategi yang digunakan untuk menggambarkan situasi reduksi ketidakpastian dalam komunikasi; strategi pasif, aktif, dan interaktif.

Fenomena peningkatan penggunaan aplikasi online dating di Indonesia secara langsung telah mendorong terjadinya cyber romantic relationship. Hal ini menjadi penting untuk diteliti lebih mendalam dikarenakan cyber romantic relationship memiliki kaitan yang cukup erat dengan tingginya ketidakpastian dalam hubungan. Berdasarkan hal tersebut peneliti akhirnya memutuskan untuk menyusun jurnal penelitian dengan judul Teori Reduksi Ketidakpastian dalam Cyber Romantic Relationship yang bertujuan untuk mengetahui bagaimana implementasi dari teori reduksi ketidakpastian terhadap fenomena cyber romantic relationship di Indonesia.

\section{TINJAUAN LITERATUR}

Penulisan ini menggunakan beberapa teori dan konsep untuk menjelaskan sejauh mana tingkat ketidakpastian dalam hubungan yang dijalin secara online atau yang sering disebut dengan cyber romantic relationship. Teori dan konsep yang digunakan yaitu teori reduksi ketidakpastian untuk menjelaskan cara-cara untuk meminimalisasi ketidakpastian dalam cyber romantic relationship dan cyber romantic relationship untuk menjelaskan secara lebih mendalam terkait proses dan juga karakteristik dari jenis hubungan tersebut.

\section{Teori Reduksi Ketidakpastian (Uncertainty Reduction Theory)}

Berger \& Calabrese pada tahun 1975 pertama kali memperkenalkan teori reduksi ketidakpastian untuk mencoba meminimalisir ketidakpastian dalam berinteraksi dengan orang lain. Mereka meyakini bahwa kehidupan sosial itu dipenuhi dengan ambiguitas.

Menurut Berger \& Calabrese (dalam Dainton \& Zelley, 2019), ada tiga asumsi yang dapat dijadikan kerangka dalam pengurangan ketidakpastian, yaitu:

a) Alasan utama dalam berkomunikasi adalah untuk mengurangi ketidakpastian di dunia dan individu di dalamnya.

b) Setiap individu pernah mengalami ketidakpastian dan pengalaman ini adalah pengalaman yang tidak menyenangkan.

c) Berger \& Calabrese mengasumsikan bahwa komunikasi merupakan alat dalam mengurangi ketidakpastian.

Tidak hanya itu, ada beberapa aksioma yang masing-masing coba menunjukkan hubungan antara konsep ketidakpastian serta delapan variabel dalam perkembangan hubungan (Berger dalam Griffin 2018), yaitu: (a) Saat komunikasi verbal Anda dengan lawan bicara Anda 
meningkat, maka level ketidakpastian akan menurun; (b) Saat ekspresi nonverbal meningkat, ketidakpastian meningkat; (c) Semakin besar ketidakpastian yang Anda rasakan, semakin banyak perilaku mencari informasi yang Anda lakukan; (d) Ketika ketidakpastian dalam hubungan tinggi maka level kedekatan dalam menjadi rendah, sebaliknya reduksi ketidakpastian akan mengarah pada kedekatan yang lebih tinggi; (e) Tingkat ketidakpastian yang tinggi akan menghasilkan tingkat timbal balik yang tinggi; (f) semakin banyak kesamaan yang kamu rasakan dengan orang lain, semakin berkurang ketidakpastian; (g) Saat ketidakpastian berkurang, rasa suka terhadap orang lain akan meningkat; (h) Adanya relasi yang berdekatan akan mengurangi ketidakpastian.

Lebih lanjut menurut Berger (1995,1997) (dalam Dainton \& Zelley, 2019), ketika kita mencari informasi mengenai realitas sosial, biasanya kita akan merancang rencana yang beragam dan kompleks, disebut juga sebagai plan based messages. Dengan demikian, ada beberapa taktik yang bisa digunakan untuk mengurangi ketidakpastian dalam berkomunikasi, yaitu:

a) Passive strategy: ketika individu mengamati lingkungan dan diam-diam mengumpulkan petunjuk tentang perilaku seseorang (Dainton \& Zelley, 2019).

i) Reactive searching: mengamati reaksi seseorang dalam suatu situasi (Littlejohn et al., 2017).

ii) Disinhibition searching: ketika seorang individu diamati dalam situasi informal, mereka cenderung bersikap lebih apa adanya (Littlejohn et al., 2017).

b) Active strategy: mencari informasi dari orang lain (Dainton \& Zelley, 2019).

c) Interactive strategy: langsung menuju dan bertanya pada sumber informasi tersebut (Dainton \& Zelley, 2019)

d) Extractive strategy: mencari informasi secara online (Griffin, 2018).

\section{Teori Reduksi Ketidakpastian Dalam Hubungan (Relational Uncertainty)}

Teori reduksi ketidakpastian yang dikembangkan oleh Berger lebih berfokus untuk menjelaskan pertemuan antar individu saat pertama kali berkenalan. Lebih lanjut, Leanne Knobloch dalam Griffin (2018) mencoba menjelaskan reduksi ketidakpastian yang terjadi pada hubungan romantisme yang terjalin antar individu.

Ketidakpastian ini terjadi ketika kita tidak lagi mencari informasi untuk mengurangi ketidakpastian, namun terjadi saat kita mulai tidak yakin pada pikiran kita terhadap individu tersebut. Lebih lanjut dijelaskan oleh Knobloch dalam Griffin (2018) mengenai relational uncertainty, yaitu keraguan tentang pikiran kita sendiri, pikiran orang lain, atau masa depan hubungan dengan keluarga atau teman.

Inisiasi awal dari terbentuknya teori relational uncertainty, adalah ketika pada transisi pasangan romantis dari hubungan romantisme biasa menjadi hubungan romantisme yang lebih serius - saat pasangan menegosiasikan arti hubungan tersebut dan apakah kemungkinan akan berlanjut. Pada fase seperti ini, tidak hanya dapat menghasilkan ketidakpastian yang tinggi, tetapi pasangan juga mengalami partner interference saat mereka belajar untuk mengkoordinasikan tujuan, rencana, dan aktivitas individu dengan cara yang tidak mengganggu satu sama lain. Knobloch percaya ketidakpastian ini dapat mengarahkan individu yang dekat dengan kita mengalami relational turbulence, yaitu perasaan emosi, marah dan sedih yang membuat mereka lebih reaktif pada sikap dan perilaku yang kita lakukan (Griffin, 2018).

Menurut Berger \& Calabrese (1975) dalam Jones (2015), ada tiga tahap yang individu lakukan pada saat pengembangan hubungan, yaitu: (a) Entry stage, tahap dimana individu mengumpulkan informasi dasar seperti nama, umur, tempat tinggal, pekerjaan, dan status perkawinan; (b) Personal stage, kepercayaan, ketakutan, nilai-nilai kehidupan, dan informasi 
personal lainnya dibagikan; (c) Exit stage, kedua belah pihak dapat memutuskan apakah hubungan akan dilanjutkan dengan terus saling berbagi informasi personal lainnya atau memutuskan untuk menghentikan hubungan.

\section{Cyber Romantic Relationship}

Karakteristik dari Cyber Romantic Relationship berbeda dengan hubungan yang berlangsung secara konvensional dalam dunia nyata atau face to face. CRR terjadi melalui pertukaran teks digital, suara, atau melalui foto baik secara asinkronik maupun sinkronik antar individu melalui internet. Absennya kehadiran fisik pada proses awal interaksi suatu hubungan dapat menyebabkan peningkatan ketidakpastian dalam hubungan karena perbedaan perspektif yang terjadi pada proses pengungkapan diri.

Komunikasi interpersonal secara online telah membantu dalam pengembangan hubungan romantis dapat membantu memberikan keintiman yang lebih besar antara dua individu daripada yang dapat ditemukan dalam hubungan tatap muka konvensional. Selain itu, hubungan melalui internet atau online memungkinkan hubungan untuk bergerak lebih cepat. Hubungan ini dapat berkembang secara pesat dikarenakan kemampuan pengirim untuk menampilkan dirinya dengan hati-hati kepada individu lain. Setiap orang memiliki kemampuan untuk mengedit pesan sebanyak yang dibutuhkan sebelum mengirimnya. Penerima cenderung membentuk atribusi positif dan ideal tentang pengirim berdasarkan informasi yang disajikan.

\section{METODE PENELITIAN}

Penelitian ini menggunakan metode pendekatan deskriptif kualitatif. Menurut Arikunto (2010), penelitian deskriptif merupakan teknik pengumpulan data berdasarkan faktor-faktor yang menjadi pendukung terhadap objek penelitian, kemudian faktor-faktor tersebut dianalisis untuk dicari peranannya.

Pada tahapan pengumpulan data penelitian, peneliti menggunakan sumber data sekunder. Menurut Marta \& Septyana, data sekunder dapat diperoleh dari buku, jurnal maupun internet yang meliputi berbagai informasi, literatur perpustakaan, serta tokoh akademis yang terkait dengan penelitian yang dilakukan.

Menurut Neuman (2017) pengumpulan mengenai berbagai literatur sebelumnya dapat disatukan dalam empat langkah yaitu: (1) Mencari semua penelitian potensial pada suatu topik atau pernyataan penelitian tertentu; (2) Mengembangkan kriteria yang konsisten dan studi layar untuk relevansi dan menyaring penelitian untuk memperoleh relevansi dan kualitas; (3) Mengidentifikasi dan mencatat informasi menjadi temuan yang luas; (4) Menarik kesimpulan berdasarkan temuan tersebut. Berikut penjelasan langkah-langkah tersebut.

1) Mencari Semua Penelitian Potensial pada Suatu Topik

Peneliti mencari jurnal dengan topik terkait teori reduksi ketidakpastian dan cyber romantic relationship dengan mempertimbangkan artikel dan literatur yang diterbitkan pada tahun 2002 s.d 2020 sehingga masih relevan dengan fenomena yang terjadi saat ini.

2) Menyaring penelitian yang relevan

Peneliti kemudian mengumpulkan artikel dengan kata kunci yang sudah ditentukan untuk dianalisis dan dikaitkan dengan fenomena terpilih yang ada di Indonesia.

3) Mengidentifikasi dan mencatat informasi menjadi temuan yang luas.

Melakukan elaborasi kasus dan konsep dari teori yang sudah dipilih dengan membandingkan jurnal yang berisikan penelitian terdahulu.

4) Menarik kesimpulan 
Dari hasil elaborasi dan analisis penelitian terdahulu dapat ditarik kesimpulan mengenai kekurangan dari teori serta pengaplikasiannya pada fenomena yang terjadi saat ini. Sehingga, dapat berisikan saran-saran untuk penelitian selanjutnya.

\section{HASIL DAN PEMBAHASAN}

Penelitian pertama yang dipilih oleh peneliti merupakan penelitian yang dilakukan oleh Ferina (2019) yang berjudul Pengelolaan Ketidakpastian pada Pengguna Aplikasi Kencan dalam Membina Hubungan Romantis (Studi Fenomenologi pada Pengguna Tinder di Jakarta). Penelitian yang telah dilakukan oleh Ferina ini menggunakan metode kualitatif dengan studi fenomenologi dan paradigma interpretif. Peneliti memilih pengguna aplikasi Tinder yang berdomisili di Jakarta dan tentunya yang sudah memahami atau memiliki pengalaman yang dapat membantu peneliti untuk melakukan penelitian ini. Melalui penelitian ini diharapkan mampu memberikan gambaran terkait perilaku dari pengguna online dating apps atau dalam konteks penelitian ini adalah aplikasi Tinder dalam mengelola ketidakpastian pada saat melakukan interaksi dengan calon pasangannya dalam menjalani romantic relationship. Selain itu, dari penelitian ini pula ditemukan bahwa uncertainty dalam romantic relationship pasti terjadi dalam kelima tahapan (inisiasi, percobaan, mengintensifikasikan, pengintegrasian, dan ikatan). Hal ini dapat dilihat dimana pada awal permulaan suatu hubungan, uncertainty itu timbul dikarenakan kedua belah pihak memiliki cara pandang yang kurang baik terhadap pengguna online dating apps tersebut. Lalu, berlanjut pada tahap pengintegrasian dan ikatan, dimana apabila saat hubungan tersebut terjalin, terdapat beberapa perbedaan diantara kedua belah pihak, baik itu perbedaan agama, nilai, budaya, bahkan hingga latar belakang. Pengelolaan ketidakpastian guna mengurangi tingkat ketidakpastian tersebut telah dilakukan oleh kedua belah pihak. Dimana ketiga strategi uncertainty reduction menjadi pilihan kedua informan. Selain itu pula, kedua informan menggunakan teknologi dengan passive strategy dengan mengobservasi dan memprediksi lifestyle dan sifat dari calon pasangan melalui informasi yang didapatkan dari halaman profil pada online dating apps ataupun akun sosial media lainnya yang terhubung dengan online dating apps tersebut.

Penelitian serupa lainnya dilakukan oleh Fox \& Anderegg pada tahun 2014. Penelitian tersebut berjudul Romantic Relationship Stages and Social Networking Sites: Uncertainty Reduction Strategies and Perceived Relational Norms on Facebook. Penelitian ini menggunakan metode survei dengan melibatkan 251 laki-laki dan 265 perempuan pengguna aktif Facebook. Tujuan dari penelitian ini untuk mengetahui bagaimana situs jejaring sosial digunakan sebagai sumber pencarian informasi terkait pasangan potensial ataupun pasangan saat ini. Melalui penelitian tersebut didapatkan hasil bahwa perilaku online yang normatif dan dapat diterima berubah seiring dengan perubahan tahapan suatu hubungan. Strategi pasif ditemukan lebih normatif pada saat sebelum pasangan mulai berkencan daripada saat setelah hubungan romantis tersebut dimulai. Sedangkan, strategi aktif ditemukan paling tidak normatif pada saat sebelum interaksi tatap muka dan paling diterima pada saat kedua individu sudah menjalin hubungan romantis.

Pada tahun 2019 Pradnya Aisyah Paramita melakukan penelitian yaitu Pengurangan Ketidakpastian Pengungkapan Perasaan Pasangan yang Terlibat dalam Cyber Romantic Relationship (CRR). Penelitian ini bertujuan untuk menganalisis reduksi ketidakpastian yang terjadi pada pasangan yang melakukan perkenalan di internet atau biasa disebut online dating. Penelitian ini menggunakan pendekatan deskriptif kualitatif dengan metode penelitian studi kasus dengan meneliti pasangan informan berusia 20-35 tahun yang terlibat hubungan jarak jauh 
yang bertemu dan berkenalan dari internet. Temuan penelitian ini adalah pasangan yang terlibat dalam interaksi melalui internet dapat mengatasi ketidakpastian dalam hubungannya melalui percakapan lewat chatting, telepon maupun video call. Ketika pasangan informan tidak pernah melakukan komunikasi tatap muka, terdapat potensi yang besar keduanya mengalami ketidakpastian ataupun keraguan pada calon pasangan. Namun dengan menerapkan kedelapan aksioma, salah satunya keterbukaan mampu membuat mengurangi ketidakpastian dan meningkatkan kepercayaan pada pasangan informan. Adapun strategi yang digunakan untuk dalam pengurangan ketidakpastian yaitu passive, active dan interactive strategy.

Kemudian terdapat penelitian yang dilakukan oleh Gibbs et al., (2015) dengan judul First Comes Love, Then Comes Google: An Investigation of Uncertainty Reduction Strategies and Self-Disclosure in Online Dating bertujuan untuk menyelidiki hubungan antara masalah privasi, perilaku pengurangan ketidakpastian, dan pengungkapan diri di antara peserta online dating, berdasarkan teori pengurangan ketidakpastian. Penelitian ini menggunakan metode survei dengan partisipan sebanyak 562 responden yang melakukan online dating. Temuan dari penelitian ini yaitu ketidakpastian akan terjadi apabila ketiga hal ini terjadi yaitu: masalah keamanan pribadi, misinterpretasi dan pengungkapan diri. Pertama, semakin besar masalah responden dalam mengalami masalah keamanan pribadi dalam online dating, semakin tinggi juga tindakan dalam mengurangi ketidakpastian. Kedua, ditemukan juga bahwa semakin besar perhatian dengan pasangan yang salah menginterpretasikan dirinya, semakin sering terjadi pengurangan ketidakpastian. Selain itu, semakin banyak peserta yang terlibat dalam pengurangan ketidakpastian, semakin besar kemungkinan mereka untuk mengungkapkan diri. Pengurangan ketidakpastian yang dilakukan oleh responden dilakukan dengan menggunakan interactive, active, extractive dan passive strategy. Dari keempat strategi ini yang paling banyak digunakan yaitu strategi interactive strategy, sedangkan yang paling sedikit digunakan yaitu extractive strategy karena banyak dari peserta responden yang belum memiliki level literasi internet yang tinggi.

Berikutnya, terdapat penelitian dengan judul The Self-Reported Reasons for SelfDisclosure and Uncertainty Reduction Strategies Used in Romantic Online Dating Relationships Compared to Face to Face Romantic Dating Relationships. Penelitian yang telah dilakukan oleh Jones pada tahun 2015 ini bertujuan untuk mengetahui bagaimana hubungan interpersonal yang dimediasi oleh komputer dapat berkembang melalui strategi pengurangan ketidakpastian dan pengungkapan diri. Hasil yang ditemukan, bahwa tidak ada perbedaan yang signifikan pada saat mencari tahu tentang orang yang berkepentingan sebelum berhubungan melalui online maupun secara langsung. Namun untuk memutuskan bahwa hubungan romantisme akan berlanjut ke arah yang lebih serius tetap membutuhkan pertemuan tatap muka sehingga bisa mengidentifikasi komunikasi nonverbal yang tidak dapat diwadahi secara online.

Penelitian dengan judul Social Networking Sites in Romantic Relationships: Attachment, Uncertainty, and Partner Surveillance on Facebook oleh Fox \& Warber (2014) bertujuan untuk menganalisis dua variabel penjelas potensial pada interpersonal electronic surveillance (IES) pada hubungan romantisme yaitu, attachment style dan ketidakpastian relasional hubungan. Penelitian dilakukan dengan melakukan survey pada pasangan dan mantan pasangan di Facebook. Hasil penelitian ini adalah dengan mempertahankan hubungan virtual ini dengan mantan pacar, dapat meningkatkan perasaan tidak pasti tentang masa depan hubungan mereka. Ketidakpastian ini akan lebih mudah dikonfirmasi jika dilakukan tanpa media sosial, karena memiliki posibilitas memiliki akhir yang lebih jelas dan lebih pasti. Salah satunya penyebabnya adalah, mereka cenderung menafsirkan konten ambigu di Facebook dengan cara 
yang negatif, yang dapat menimbulkan konflik atau ketegangan hubungan. Selain itu, apabila mantan pasangan ini tetap berteman di Facebook, salah satu dari mereka cenderung merasa bahwa masih ada masa depan untuk hubungan romantisme mereka.

Penelitian yang dilakukan oleh Ramirez et al., (2015) dengan judul When Online Dating Partners Meet Offline: The Effect of Modality Switching on Relational Communication Between Online Daters menggunakan metode survei dengan melibatkan sampel sebanyak 433 orang yang berpartisipasi dalam online dating selama 3 bulan. Hasil yang didapat menunjukkan bahwa data online seperti profil dapat dijadikan panduan dalam mengkonstruksikan detail pasangan mereka di dunia offline. Namun tidak sedikit dari individu yang melakukan sedikit manipulasi, melebih-lebihkan data dan foto pada profil sehingga memberikan kesan positif pada halaman profil mereka. Akibatnya, pasangan yang melakukan pertemuan tatap muka relatif lebih awal mungkin dapat menerima perbedaan kecil antara harapan dan kenyataan mereka, tetapi pasangan yang menunggu terlalu lama mungkin mengalami peningkatan ketidakpastian ketika orang yang berinteraksi dengan mereka gagal memenuhi harapan mereka.

Penelitian terakhir oleh Sa'adatina (2017) dengan judul Penggunaan Media Sosial dalam Dinamika Hubungan Pacaran: Studi Terhadap Penggunaan Instagram pada Pasangan Berpacaran. Penelitian ini menggunakan tipe deskriptif kualitatif dengan pendekatan fenomenologi dengan subjek penelitian berjumlah enam pasangan berpacaran rentan usia 18-25 tahun. Tujuan penelitian ini untuk melihat bagaimana penggunaan Instagram dalam dinamika hubungan berpacaran, mulai dari tahap perkenalan, sampai ke tahap pertukaran stabil. Dimana pada setiap tahapan Instagram punya peranan yang berbeda-beda. Teori yang digunakan dalam penelitian ini adalah teori penetrasi sosial dan teori reduksi ketidakpastian. Temuan dari penelitian ini adalah tidak semua informan menggunakan Instagram pada masa penjajakan. Sebagiannya menggunakan Instagram messenger hanya sebagai media komunikasi. Penggunaan Instagram hanya berlaku pada masa awal berpacaran, dimana digunakan sebagai penarik perhatian pasangan dan tolak ukur dalam pemilihan calon pasangan. Adapun temuan lainnya yaitu, untuk mereduksi ketidakpastian dalam hubungan, mereka cenderung menggunakan strategi pasif untuk memperoleh informasi detail yang berkaitan dengan pasangannya.

Penulis telah melakukan pengumpulan data melalui studi literatur yang bertujuan untuk melihat gambaran realistik pada proses pengurangan ketidakpastian pada pasangan yang menjalin hubungan romantisme di dunia maya. 
Secara singkat, hasil diskusi dapat dilihat melalui tabel di bawah ini:

Tabel 1

Literatur Terdahulu

\begin{tabular}{|c|c|c|c|}
\hline No & Judul Penelitian dan Penulis & $\begin{array}{l}\text { Teori Penelitian dan } \\
\text { Penerapannya }\end{array}$ & Metode Penelitian \\
\hline 1. & $\begin{array}{l}\text { Pengelolaan Ketidakpastian } \\
\text { pada Pengguna Aplikasi } \\
\text { Kencan dalam Membina } \\
\text { Hubungan Romantis (Studi } \\
\text { Fenomenologi pada } \\
\text { Pengguna Tinder di Jakarta). } \\
\text { Ferina (2019). }\end{array}$ & $\begin{array}{l}\text { Menggunakan URT dan } \\
\text { relational uncertainty dalam } \\
\text { penelitian. } \\
\text { Menggunakan strategi pasif, } \\
\text { aktif dan interaktif untuk } \\
\text { mengurangi ketidakpastian. } \\
\text { Menggunakan aksioma } \\
\text { pertama, kedua, ketiga dan } \\
\text { keempat. }\end{array}$ & $\begin{array}{l}\text { Kualitatif, studi } \\
\text { fenomenologi } \\
\text { dengan subjek } \\
\text { penelitian pengguna } \\
\text { heterosexual Tinder } \\
\text { di Jakarta. }\end{array}$ \\
\hline 2. & $\begin{array}{l}\text { Romantic Relationship Stages } \\
\text { and Social Networking Sites: } \\
\text { Uncertainty Reduction } \\
\text { Strategies and Perceived } \\
\text { Relational Norms on } \\
\text { Facebook. }\end{array}$ & $\begin{array}{l}\text { Menggunakan URT sebagai } \\
\text { teori utama dan teori } \\
\text { romantic relationships and } \\
\text { norms sebagai teori } \\
\text { pendukung. }\end{array}$ & $\begin{array}{l}\text { Pendekatan } \\
\text { kuantitatif dengan } \\
\text { metode survei } \\
\text { dengan melibatkan } \\
251 \text { laki-laki dan } \\
265 \text { perempuan } \\
\text { heterosexual } \\
\text { pengguna aktif } \\
\text { Facebook di } \\
\text { Midwestern } \\
\text { University. }\end{array}$ \\
\hline 3. & $\begin{array}{l}\text { Pengurangan Ketidakpastian } \\
\text { Pengungkapan Perasaan } \\
\text { Pasangan yang Terlibat } \\
\text { dalam Cyber Romantic } \\
\text { Relationship (CRR). } \\
\text { Paramita (2019). }\end{array}$ & $\begin{array}{l}\text { Menggunakan URT sebagai } \\
\text { teori utama dan } \\
\text { mengaplikasikannya untuk } \\
\text { mereduksi ketidakpastian } \\
\text { dalam hubungan romantisme } \\
\text { secara online. } \\
\text { Pengurangan ketidakpastian } \\
\text { dengan menggunakan } \\
\text { strategi active, interactive } \\
\text { dan passive. }\end{array}$ & $\begin{array}{l}\text { Penelitian deskriptif } \\
\text { data kualitatif } \\
\text { dengan metode } \\
\text { penelitian studi } \\
\text { kasus individu yang } \\
\text { terlibat hubungan } \\
\text { jarak jauh antar } \\
\text { pasangan } \\
\text { heterosexual, } \\
\text { dimana pasangan } \\
\text { belum sampai tahap } \\
\text { komitmen dan } \\
\text { belum pernah } \\
\text { bertemu. }\end{array}$ \\
\hline
\end{tabular}




\begin{tabular}{|c|c|c|c|}
\hline 4. & $\begin{array}{l}\text { First Comes Love, Then } \\
\text { Comes Google: An } \\
\text { Investigation of Uncertainty } \\
\text { Reduction Strategies and } \\
\text { Self-Disclosure in Online } \\
\text { Dating. } \\
\text { Gibbs et al., (2015). }\end{array}$ & $\begin{array}{l}\text { Meneliti implikasi dari } \\
\text { computer-mediated } \\
\text { communication dan } \\
\text { kaitannya dengan konteks } \\
\text { uncertainty reduction theory, } \\
\text { self-disclosure, privacy dan } \\
\text { warranting. } \\
\text { Penggunaan aksioma ketiga. }\end{array}$ & $\begin{array}{l}\text { Menggunakan } \\
\text { metode survei } \\
\text { dengan partisipan } \\
\text { sebanyak total } 562 \\
\text { responden laki-laki } \\
\text { dan perempuan } \\
\text { yang aktif dalam } \\
\text { melakukan online } \\
\text { dating. }\end{array}$ \\
\hline 5. & $\begin{array}{l}\text { Self-Reported Reasons for } \\
\text { Self-Disclosure and } \\
\text { Uncertainty Reduction } \\
\text { Strategies Used in Romantic } \\
\text { Online Dating Relationships } \\
\text { Compared to Face to Face } \\
\text { Romantic Dating } \\
\text { Relationships. } \\
\text { Jones (2015). }\end{array}$ & $\begin{array}{l}\text { Self-disclosure sebagai salah } \\
\text { satu strategi untuk } \\
\text { mengetahui satu sama lain } \\
\text { dalam hubungan online } \\
\text { untuk mengurangi } \\
\text { ketidakpastian. }\end{array}$ & $\begin{array}{l}\text { Menggunakan } \\
\text { metode survei } \\
\text { menggunakan link } \\
\text { yang } \\
\text { didistribusikan } \\
\text { melalui Facebook } \\
\text { kepada pelajar yang } \\
\text { terdaftar dalam } \\
\text { institusi privat } \\
\text { untuk pendidikan } \\
\text { tinggi di Northeast. }\end{array}$ \\
\hline 6. & $\begin{array}{l}\text { Social Networking Sites in } \\
\text { Romantic Relationships: } \\
\text { Attachment, Uncertainty, and } \\
\text { Partner Surveillance on } \\
\text { Facebook. } \\
\text { Fox \& Warber (2014). }\end{array}$ & $\begin{array}{l}\text { Attachment style dan URT } \\
\text { sebagai kerangka teoritis } \\
\text { yang dapat menjelaskan } \\
\text { interpersonal electronic } \\
\text { surveillance. } \\
\text { Penggunaan strategi pasif } \\
\text { untuk memantau aktivitas } \\
\text { mantan pasangan di } \\
\text { Facebook. Penggunaan } \\
\text { aksioma kelima. }\end{array}$ & $\begin{array}{l}\text { Menggunakan } \\
\text { metode survei pada } \\
\text { pasangan dan } \\
\text { mantan pasangan di } \\
\text { Facebook. }\end{array}$ \\
\hline
\end{tabular}




\begin{tabular}{|c|c|c|c|}
\hline 7. & $\begin{array}{l}\text { When Online Dating Partners } \\
\text { Meet Offline: The Effect of } \\
\text { Modality Switching on } \\
\text { Relational Communication } \\
\text { Between Online Daters. }\end{array}$ & $\begin{array}{l}\text { Menggunakan expectancy } \\
\text { violations theory untuk } \\
\text { menginvestigasi bagaimana } \\
\text { informasi sosial } \\
\text { dikumpulkan selama } \\
\text { pertukaran dampak dari } \\
\text { penilaian sosial dan hasil } \\
\text { relational. } \\
\text { Bagaimana pengurangan } \\
\text { suatu ketidakpastian } \\
\text { berkaitan dengan } \\
\text { meningkatkan pencarian } \\
\text { informasi. } \\
\text { Berfokus pada berbagai } \\
\text { proses seperti self- } \\
\text { presentation, self-disclosure, } \\
\text { dan uncertainty reduction } \\
\text { selama melakukan online } \\
\text { dating. }\end{array}$ & $\begin{array}{l}\text { Metode survei } \\
\text { dengan sampel } \\
\text { sebanyak } 433 \\
\text { partisipan yang } \\
\text { menjalani online } \\
\text { dating selama } 3 \\
\text { bulan. }\end{array}$ \\
\hline 8. & $\begin{array}{l}\text { Penggunaan Media Sosial } \\
\text { dalam Dinamika Hubungan } \\
\text { Berpacaran: Studi Terhadap } \\
\text { Penggunaan Instagram pada } \\
\text { Pasangan Berpacaran. }\end{array}$ & $\begin{array}{l}\text { Menggunakan teori penetrasi } \\
\text { sosial dan URT. } \\
\text { Penggunaan aksioma ketiga, } \\
\text { keempat, dan ketujuh. } \\
\text { Pengurangan ketidakpastian } \\
\text { dengan melakukan strategi } \\
\text { pasif. } \\
\text { Penggunaan Instagram } \\
\text { sebagai medium reduksi } \\
\text { ketidakpastian dalam } \\
\text { hubungan yang sedang } \\
\text { berjalan (relational } \\
\text { uncertainty). }\end{array}$ & $\begin{array}{l}\text { Deskriptif kualitatif } \\
\text { dengan pendekatan } \\
\text { fenomenologi } \\
\text { dengan subjek } \\
\text { penelitian enam } \\
\text { pasangan } \\
\text { heterosexual } \\
\text { rentang usia 18-25 } \\
\text { tahun. }\end{array}$ \\
\hline
\end{tabular}

Dalam penelitian pertama yang dilakukan oleh Ferina (2019) ditemukan hasil bahwa ketidakpastian dalam hubungan romantis terjadi dalam setiap tahapan. Terdapat lima tahapan yang dalam teori ketidakpastian menurut Mark \& Daly (2002) dalam Ferina (2019) sehingga dapat dipetakan sebagai berikut:

1. Tahap inisiasi: tahapan ini terjadi karena pasangan informan memiliki pandangan yang buruk pada individu yang menggunakan aplikasi Tinder sebagai sarana pencarian pasangan.

2. Tahap percobaan: kedua informan akhirnya memutuskan untuk bertemu dan mengenal satu sama lain secara tatap muka. Pada tahap inilah kedua informan memanfaatkan game untuk 
bertanya dan menggali informasi personal. Di tahap ini akhirnya, keduanya mulai saling percaya satu sama lain dan muncul keterbukaan untuk lebih dalam lagi bertukar informasi personal. Di tahap percobaan ini kedua informan mengetahui adanya perbedaan dari segi agama, budaya, dan nilai yang dianut. Lebih lanjut fenomena yang terjadi sesuai dengan tahapan yang disebutkan oleh Knobloch dalam Griffin (2018). Ketika kedua informan sudah saling mengenal lebih dekat, dan mengetahui perbedaan-perbedaan yang dimiliki keduanya yaitu mulai dari kepercayaan, kebudayaan dan nilai yang dipegang, maka saat hubungan sudah terjalin ketidakpastian ini pun masih terjadi karena adanya keraguan tentang pikiran kita sendiri, orang lain serta masa depan hubungan mereka atau yang disebut dengan relational uncertainty.

3. Tahap mengintensifikasikan: Tahap ini ditandai ketika keduanya mulai semakin akrab. Mereka mulai menunjukkan keseriusan dengan mengajak calon pasangan mereka bertemu dan mengenal orang tua masing-masing. Di tahap ini informan perempuan mengalami kecemasan dan ketidakpastian dikarenakan pertemuan ini merupakan kali pertama ia akan bertemu dengan keluarga calon pasangannya. Untuk mengurangi ketidakpastian ia melakukan ketiga strategi yaitu pasif, aktif dan interaktif. Proses pencarian ini sesuai dengan bunyi aksioma ketiga oleh Berger, yaitu semakin besar ketidakpastian yang anda rasakan, maka semakin banyak perilaku mencari informasi yang anda lakukan.

4. Tahap pengintegrasian: Pada tahap ini keduanya yakin untuk menjalin komitmen sebagai pasangan. Keduanya semakin mengenal satu sama lain, termasuk mendalami perbedaan yang awalnya muncul. Dimana menurut Ball Rokeach dalam Gudykunst \& Kim (1997) dalam Ferina (2019), ketidakpastian dan kecemasan akan selalu dialami oleh individu dengan budaya baru. Menurut Berger \& Calabrese (1975) dalam Jones (2015), tahapan ini sudah masuk di tahapan exit stage, dimana keduanya sudah saling bertukar informasi personal lebih dalam dan sedang memutuskan apakah hubungan keduanya akan berlanjut ke tahap yang lebih serius atau akan memutuskan untuk menghentikan hubungan.

5. Ikatan: Tahap terakhir inilah kedua informan menyatakan bahwa sudah berkomitmen untuk melanjutkan hubungan ke jenjang yang lebih serius. Perbedaan-perbedaan yang dimiliki keduanya dapat diatasi dengan adanya sifat keterbukaan, kemampuan komunikasi yang baik dan saling memahaminya. Hal ini sesuai dengan bunyi aksioma pertama dan kedua oleh Berger dalam Griffin (2018) yaitu keduanya melakukan komunikasi baik untuk mengurangi level ketidakpastian, serta perilaku nonverbal yang sudah mereka pahami dengan baik sehingga tidak lagi menimbulkan ketidakpastian dan ambiguitas. Dikarenakan ketidakpastian diantara keduanya semakin berkurang maka aksioma keempat pun berlaku yaitu level kedekatan keduanya pun meningkat.

Dengan menggunakan definisi dari strategi aktif, pasif, dan interaktif yang dikemukakan oleh Berger \& Calabrese, pada penelitian kedua yang dilakukan oleh Fox \& Anderegg (2014) ditemukan bahwa perilaku strategi pasif masih terbilang normatif dan wajar dilakukan untuk mengurangi ketidakpastian dalam perkenalan. Misalnya dengan melihat-lihat foto profil, atau post pada halaman Facebook calon pasangan. Ketika kedua pasangan akhirnya memutuskan untuk berkencan, mereka akan cenderung meninggalkan Facebook sebab aplikasi ini dianggap hanya berguna untuk mengurangi ketidakpastian dan untuk mencari informasi sebanyakbanyaknya sebelum akhirnya memutuskan untuk bertemu secara offline.

Pada pasangan dewasa, terkadang hubungan romantisme juga mengalami turbulensi, atau menurut Knobloch dalam Griffin (2018) disebut relational turbulence, yaitu perasaan emosi, 
marah atas pasangan kita yang dapat menyebabkan ketidakpastian dalam keseriusan hubungan yang telah berjalan. Facebook dapat berguna dalam membantu kita dalam mengamati aktivitas pasangan kita sehingga ketidakpastian dapat direduksi. Strategi kedua yaitu interaktif, juga dianggap kurang pantas baik bagi laki-laki maupun perempuan. Bagi perempuan pada tahapan awal, mereka cenderung lebih suka mencari informasi secara diam-diam dibandingkan langsung bertanya ke lawan bicara sehingga tidak dianggap agresif. Sedangkan bagi laki-laki, mereka memiliki stereotype di dunia maya sebagai pribadi yang tidak se-ekspresif perempuan. Pada intinya keduanya tidak ingin dilihat aksi pendekatannya dilihat oleh teman-teman Facebooknya. Sehingga strategi interaktif juga tidak dapat diaplikasikan sebagai strategi pengurangan ketidakpastian. Strategi terakhir yaitu active, dianggap tidak wajar karena dapat diartikan sebagai tindakan kurang sopan apabila sebelumnya tidak pernah melakukan pertemuan tatap muka. Namun active strategy lebih diterima pada saat kedua individu telah menjalin hubungan romantis. Dapat disimpulkan, pada penelitian ini pengaplikasian strategi dalam pengurangan ketidakpastian hanya berlaku strategi pasif. Adapun modifikasi dari penelitian ini dengan menambahkan teori romantic relationships and norms yang lebih dapat bisa menjelaskan mengapa strategi ketidakpastian ini tidak dapat diaplikasikan seluruhnya.

Menurut Berger \& Calabrese (dalam Dainton \& Zelley, 2019) diyakini bahwa kehidupan sosial itu dipenuhi oleh ambiguitas. Selain itu, ketidakpastian adalah suatu hal yang tidak bisa dihindari saat kita berinteraksi dengan orang lain. Terkait dengan fenomena cyber romantic relationship, absennya kehadiran fisik pada proses awal interaksi suatu hubungan menyebabkan peningkatan ketidakpastian dalam hubungan karena adanya perbedaan perspektif yang terjadi pada proses pengungkapan diri. Pengaplikasian teori yang dipaparkan Berger \& Calabrese dapat ditemukan pada penelitian ketiga yang dilakukan oleh Paramita (2019), dimana ketidakpastian menjadi sangat kompleks sebab satu pasangan dapat mengalami lebih dari satu ketidakpastian dan ketidakpastian ini dapat saling berkaitan. Tanda-tanda munculnya ketidakpastian ditandai dengan munculnya ketidakpastian bahwa hubungan keduanya akan melangkah ke level yang lebih tinggi. Namun ketidakpastian yang terjadi ini dapat diatasi dengan strategi pasif, dengan hanya mengamati calon pasangan bagaimana ia berinteraksi dengan orang lain. Kemudian cara aktif dengan mencari tahu dari keluarga, teman atau rekan yang intensitas pertemuannya lebih tinggi dengan individu tersebut. Dan yang terakhir dengan strategi interaktif, yaitu komunikasi secara langsung. Namun pada penelitian ini, extractive strategy tidak diaplikasikan.

Penggunaan aksioma pada informan penelitian ini di tahapan pengenalan yaitu aksioma pertama, ketiga, keempat, keenam, ketujuh, dan kedelapan. Lebih lanjut dipaparkan sebagai berikut:

1. Aksioma pertama: Pasangan informan pertama melakukan komunikasi secara intens baik melalui whatsapp messenger, video call sehingga ketidakpastian dalam hubungan mereka semakin berkurang.

2. Aksioma kedua: Ketika ungkapan nonverbal semakin hangat, maka ketidakpastian akan menurun. Walaupun tidak melakukan komunikasi tatap muka, namun ungkapan non-verbal ini dirasakan lewat interaksi video call.

3. Aksioma ketiga: Ketika ketidakpastian terjadi, pasangan informan ketiga mengatakan melakukan strategi active, interactive dan passive. Pihak perempuan cenderung melakukan strategy interactive. Sedangkan pada pasangan informan pertama, lebih banyak melakukan strategi active yaitu dengan bertanya ke anggota keluarga.

4. Aksioma keempat: Kedekatan informan semakin terjadi karena adanya keterbukaan hanya ditemukan pada pasangan informan keempat. 
5. Aksioma kelima: Pada pasangan informan keempat, pada awalnya keduanya masih saling mengira-ngira karena proses pengenalan dan percakapan hanya dilakukan di Instagram. Namun karena keduanya sama-sama terbuka dan memutuskan untuk melanjutkan hubungan ke jenjang yang lebih serius, maka proses pertukaran informasi personal terjadi lebih dalam dan intensitas timbal balik yang lebih tinggi antara kedua pasangan dengan melakukan pencarian informasi secara interaktif.

6. Aksioma keenam: Adanya kesamaan minat terhadap gaming yang membuat salah informan ketiga menjadi tertarik pada pasangannya. Sedangkan pada informan ke empat mengaku terdapat kesamaan minat terhadap isu-isu yang sama seperti agama dan gender.

7. Aksioma ketujuh: Pada pasangan informan kedua, saat melakukan pengenalan melalui Tinder keduanya memutuskan untuk menjauh karena ketidakpastian yang tinggi. Namun akhirnya memutuskan untuk melanjutkan hubungan kembali dan mengurangi ketidakpastian dengan cara interactive strategy.

8. Aksioma kedelapan: Pada pasangan informan pertama, keduanya merupakan keluarga jauh yang perkenalannya dibantu oleh salah satu anggota keluarga. Karena adanya relasi yang berdekatan, mereka memutuskan untuk berkenalan.

Salah satu informan yang ada dalam penelitian Paramita (2019) menjelaskan salah satu tahapan online stages romantic relationship, yaitu curiosity. Menurut Zunin (1972) dalam Paramita (2019), dalam empat menit pertama individu dapat memutuskan tetap melanjutkan perkenalan lebih lanjut atau mengakhirinya. Jika individu menyukai kesan pertamanya dan dinyatakan tertarik maka kedua individu akan saling melakukan interaksi lebih jauh lagi. Komunikasi interpersonal secara online dapat bergerak lebih cepat dibandingkan dalam hubungan tatap muka konvensional. Hal ini terjadi karena setiap orang memiliki kemampuan untuk mengedit pesan sebanyak yang dibutuhkan sebelum mengirimnya sehingga menimbulkan rasa penasaran yang lebih besar pada komunikan. Sehingga teori reduksi ketidakpastian dalam penelitian ini dapat diaplikasikan sebagian dengan mengimplementasikannya dengan teori lain yaitu cyber romantic relationship.

Penelitian keempat yang dilakukan oleh Gibbs et al., (2015) bertujuan untuk mengeksplorasi cara peserta online dating dalam memverifikasi dan berbagi informasi pribadi dengan orang yang mereka temui secara online melalui penggunaan strategi pengurangan ketidakpastian. Hal ini sesuai dengan bunyi aksioma ketiga yang digagas oleh Berger yaitu, semakin besar rasa ketidakpastian maka semakin banyak perilaku mencari informasi yang Anda lakukan. Secara garis besar penelitian ini menggunakan seluruh strategi pengurangan ketidakpastian dalam online dating yaitu dengan interactive, active, extractive dan passive strategy. Teori reduksi ketidakpastian memainkan peran penting dalam pembentukan hubungan online. Karena perkembangan teknologi informasi dan komunikasi semakin berkembang, begitu pula dengan interaksi sosial — hubungan keduanya akan terus berputar membentuk kembali pola komunikasi antara orang asing, teman, keluarga, dan pasangan romantis sehingga diperlukannya reduksi ketidakpastian di dalam proses komunikasi.

Dalam penelitian ini pun menggunakan teori pendukung yaitu computer-mediated communication, self-disclosure, privacy dan warranting yang membantu menjelaskan secara lebih dalam lagi hubungannya dengan teori reduksi ketidakpastian. Dalam computer-mediated communication, profil yang ditampilkan pada dunia maya memungkinkan individu untuk melakukan "selective self presentation" dimana hal ini dapat menyebabkan misinterpretasi bagi seseorang yang ingin melakukan hubungan jangka panjang dan berniat untuk melakukan 
interaksi tatap muka. Sedangkan hubungannya dengan self-disclosure dan privacy, kita dihadapkan dengan norma-norma yang berlaku di lingkungan sekitar kita sehingga tidak mudah bagi seorang individu dalam membuka diri khususnya di situs online dating salah satunya juga untuk faktor keamanan. Maka dari itu seseorang yang berniat atau sedang menjalani online dating melakukan ketiga strategi pengurangan ketidakpastian, baik dengan melakukan pengecekan public records dengan menggunakan Google, melakukan komparasi serta mengobservasi aktivitas profil pada beberapa website, hingga bertanya langsung ke sumbernya dan orang terdekat calon pasangan. Reduksi ketidakpastian tersebut berkaitan dengan warranting dalam online dating, dimana seorang individu mencari keterkaitan informasi yang didapatkan dari sumber online dan offline sebelum memutuskan untuk melanjutkan ke tahapan yang lebih serius. Maka dari itu, sesuai penjelasan di atas, mayoritas responden memilih strategi interaktif sebagai strategi yang paling dapat diandalkan dalam upaya pengurangan ketidakpastian dalam online dating.

Penelitian kelima yang dilakukan oleh Jones (2015) bertujuan untuk mengetahui bagaimana hubungan interpersonal yang dimediasi oleh komputer dapat berkembang melalui strategi pengurangan ketidakpastian dan pengungkapan diri.

Menurut Solomon \& Knobloch (2001) dalam Jones (2015) kekurangan informasi dapat mencegah kontak dan rencana untuk tujuan hubungan pada masa depan. Terdapat 4 tahapan untuk mengurangi ketidakpastian:

1. Entry: menggunakan strategi pasif untuk mencari informasi tentang orang yang diminati, seperti melihat profil pada online dating apps, blog, foto, media sosial, dan informasi lainnya yang disediakan oleh situs dating tersebut. Pada penelitian ini dapat dilihat pada, daters berusaha untuk membuka informasi lebih banyak terkait dirinya sendiri untuk meningkatkan ketertarikan dari orang lain sebelum menerima informasi. Selain itu, daters juga cenderung melakukan pengungkapan diri secara lebih pada saat ada momen untuk melakukan pertukaran informasi.

2. Self-disclosure: Pada saat kontak telah terjadi dan komunikasi sudah dimulai, kedua orang yang berinteraksi tersebut mulai mengungkapkan informasi lainnya tentang satu orang ke orang lainnya dengan menggunakan strategi interaktif. Self-disclosure terjadi untuk membangun hubungan, meningkatkan kepercayaan, menetapkan tingkat kenyamanan, dan mendapatkan informasi tambahan tentang orang tersebut. Pada penelitian ini, tidak ditemukan profil untuk mendapatkan informasi, sehingga kebutuhan untuk meningkatkan self-disclosure menjadi sangat penting untuk melanjutkan ke tahap exit stage.

3. Validation: Menurut Gibbs et al., (2011) dalam Jones (2015) kedua belah pihak melakukan penelitian lebih lanjut tentang orang yang diminati dengan mencari public records, nilai properti lain, dan prospect pada situs lain untuk melihat apa yang sudah diungkapkan oleh orang tersebut akan dirinya adalah suatu hal yang benar. Dalam penelitian ini, tahap validasi dilakukan dengan melakukan penelitian terhadap orang yang disukai secara langsung, dimana responden yang menjawab "iya" untuk memiliki hubungan tatap muka, sebanyak $71 \%$ menjawab setuju, 24\% menjawab tidak bisa memilih, dan 5\% setuju terhadap pernyataan "dalam hubungan tatap muka, saya mencoba untuk mencari informasi terkait orang yang disukai untuk menentukan seberapa banyak informasi yang akan saya ungkapkan kepada mereka".

4. Exit: Kedua belah pihak telah menentukan apakah mereka menginginkan hubungan yang lebih jauh, atau melanjutkan berkomunikasi, berdasarkan informasi yang didapatkan dari tahap satu sampai tiga. Dalam penelitian ini, exit stage menentukan interaksi masa depan. 
Penelitian keenam oleh Fox \& Warber (2014) menjelaskan bagaimana peran Facebook dalam membantu mereka dalam mereduksi rasa cemas dan ketidakpastian oleh pasangan dan mantan pasangan. Namun pada penelitian ini ditemukan bahwa peran Facebook tidak mampu mereduksi ketidakpastian yang terjadi di dalam hubungan. Dengan adanya Facebook, mantan pasangan dapat dengan mudah melakukan pasif strategi yaitu dengan mengamati aktivitas pada timeline Facebook mantan pasangan. Namun nyatanya aktivitas ini semakin menimbulkan ketidakpastian dan ambiguitas. Pada masa sebelum adanya media sosial, hal ini tidak mungkin dilakukan sehingga pemutusan hubungan yang terjadi dapat lebih jelas. Aksioma yang tepat untuk menjelaskan perilaku ini ialah aksioma kelima, yaitu ketika ketidakpastian tinggi maka tingkat resiprositas atau timbal balik juga tinggi. Untuk perilaku ini, penulis memperhitungkan attachment style yang dimiliki oleh responden, walaupun timbal balik yang diterima tidak sama.

Adapun teori attachment style yang lebih memiliki pengaruh pada interpersonal electronic surveillance (IES) atau pengawasan yang dilakukan seseorang pada aktivitas pasangan mereka di jejaring sosial. Pasangan yang melakukan IES cenderung memiliki tingkat kecemasan dan ketakutan yang tinggi pada pasangan mereka. Sehingga dapat disimpulkan dorongan perilaku pengawasan ini bukanlah untuk mereduksi ketidakpastian dalam hubungan, namun karena attachment style yang dimiliki oleh individu, dimana mereka yakin ketika pengawasan dilakukan maka mereka dapat merasa lebih aman dan terjamin untuk melanjutkan hubungannya.

Pengertian konvensional terhadap hubungan romantis terkadang bergantung pada kesempatan seseorang untuk bertemu dengan orang lainnya dalam kedekatan geografisnya, seperti di tempat kerja, di pasar swalayan, maupun lingkungan sosial. Menurut Heino, Ellison \& Gibbs (2010) pada Ramirez (2015) situs online dating membebaskan diri dari paradigma tersebut dengan menyediakan individu informasi yang lebih banyak tentang kumpulan calon kandidat yang lebih luas daripada yang tersedia dalam pertemuan tatap muka. Dimana sebagai hasil, online dating dijadikan cara yang paling mudah bagi orang dewasa yang masih lajang untuk menemukan orang lain yang sedang mencari hubungan romantis.

Berkaitan dengan hal tersebut, penelitian ketujuh dilakukan oleh Ramirez (2015) menunjukkan bahwa data online seperti profil dapat dijadikan panduan dalam mengkonstruksikan detail pasangan mereka di dunia offline. Namun tidak sedikit dari individu yang melakukan sedikit manipulasi, melebih-lebihkan data dan foto pada profil sehingga memberikan kesan positif pada halaman profil mereka. Akibatnya, pasangan yang melakukan pertemuan tatap muka relatif lebih awal mungkin dapat menerima perbedaan kecil antara harapan dan kenyataan mereka, tetapi pasangan yang menunggu terlalu lama mungkin mengalami peningkatan ketidakpastian ketika orang yang berinteraksi dengan mereka gagal memenuhi harapan mereka. Selain itu, melalui penelitian ini juga diungkapkan bahwa pasangan yang terhubung pada awal pertukaran kepada interaksi tatap muka melaporkan point of view yang lebih positif, adanya pengurangan ketidakpastian, dan meningkatkan pencarian informasi. Dimana, semakin tingginya ketidakpastian tersebut, akan berlanjut pada meningkatkan pencarian informasi.

Hal ini sejalan dengan beberapa aksioma yang menunjukkan hubungan antara konsep ketidakpastian serta delapan variabel dalam perkembangan hubungan (Berger dalam Griffin 2018), yaitu: (a) Saat komunikasi verbal Anda dengan lawan bicara Anda meningkat, maka level ketidakpastian akan menurun; (b) Saat ekspresi nonverbal meningkat, ketidakpastian meningkat; (c) Semakin besar ketidakpastian yang Anda rasakan, semakin banyak perilaku mencari informasi yang Anda lakukan; (d) Ketika ketidakpastian dalam hubungan tinggi maka level 
kedekatan dalam menjadi rendah, sebaliknya reduksi ketidakpastian akan mengarah pada kedekatan yang lebih tinggi; (e) Tingkat ketidakpastian yang tinggi akan menghasilkan tingkat timbal balik yang tinggi; (f) semakin banyak kesamaan yang kamu rasakan dengan orang lain, semakin berkurang ketidakpastian; (g) Saat ketidakpastian berkurang, rasa suka terhadap orang lain akan meningkat; (h) Adanya relasi yang berdekatan akan mengurangi ketidakpastian.

Penelitian yang dilakukan oleh Sa'adatina (2017) meneliti bagaimana pasangan informan ini melakukan pengurangan ketidakpastian dalam tiap tahapan hubungan mulai dari tahap pengenalan hingga tahap berkomitmen. Seperti pada bunyi aksioma ketiga yang dicetuskan oleh Berger dalam Griffin (2018) ketika besar ketidakpastian dirasakan, maka semakin banyak perilaku mencari informasi yang Anda lakukan. Pada penelitian ini penggunaan Instagram berfungsi dalam mereduksi ketidakpastian dimana dimanfaatkan sebagai pencarian informasi terkait pasangan potensialnya, serta sebagai pengganti komunikasi tatap muka. Sehingga penggunaan strategi yang digunakan yaitu strategi pasif. Ketertarikan pasangan tidak langsung muncul pada awal interaksi. Di masa penjajakan biasanya mereka menarik calon pasangan dengan mengunggah foto terbaik ataupun foto pribadi (Instastory), berinteraksi dalam kolom komentar, hingga memberikan tanda like pada unggahan foto pasangan.

Proses ketertarikan berlangsung cepat dan didasarkan dari penilaian dari unggahan serta pertemanan online mereka. Di samping itu, proses kenaikan level hubungan ini dapat dikaitkan dengan bunyi aksioma ketujuh dimana ketika rasa suka pada seseorang meningkat, maka ketidakpastian akan menurun. Dimana hal ini mengarah ke tahap akhir atau exit stage menurut Berger dalam Jones (2015) yaitu tahap komitmen atau masa awal pacaran. Pada penelitian ini pun disebutkan bahwa bentuk aksioma keempat yaitu kedekatan dirasakan ketika pasangan informan mulai terbuka dengan saling bertukar password Instagram pribadinya.

Pada tahap ketiga, Instagram masih tidak lepas dari perannya dalam menjadi media reduksi ketidakpastian dalam hubungan. Seperti yang dipaparkan oleh Knobloch dalam Griffin (2018), ketidakpastian yang terjadi pada hubungan romantisme yang terjadi antar individu bisa disebabkan oleh keraguan pikiran kita sendiri, pikiran tentang orang lain atau masa depan hubungan. Tidak jarang juga terjadi relational turbulence, yaitu perasaan emosi ketika ketidakpastian ini tidak dapat direduksi. Pada Instagram biasanya turbulance ini terjadi karena rendahnya kualitas komunikasi yang bermula karena penempatan tanda like/suka pada orang lain, pesan singkat sampai penerimaan pertemanan yang dianggap bisa merusak hubungan. Peran Instagram disini adalah sebagai media pengalihan kekesalan dan balas dendam secara halus sehingga bisa mengurangi ketegangan dalam hubungan seperti menghapus foto pasangan di Instagram, unfollow atau block pertemanan lawan jenis yang berisiko menimbulkan masalah hingga merusak hubungan.

\section{KESIMPULAN}

Setiap individu akan melakukan reduksi komunikasi untuk meminimalisir ketidakpastian pada hubungan yang dijalaninya. Ketidakpastian menjadi hal yang krusial dalam hubungan interpersonal, karena ketidakpastian yang dialami oleh satu individu akan berbeda dengan yang lainnya. Atau, dapat terjadi lebih dari satu ketidakpastian yang dialami oleh individu.

Teori ketidakpastian yang diaplikasikan pada penelitian ini tidak hanya berlaku pada tahap pengenalan saja namun lebih dalam hingga ke proses pembinaan hubungan. Hal ini dilakukan untuk memudahkan proses pemutusan hubungan atau pembinaan hubungan dengan melibatkan semakin banyak pertukaran informasi personal. Namun dalam melakukan aplikasi reduksi ketidakpastian, terdapat beberapa perbedaan strategi yang dilakukan di tiap literatur yang 
telah diidentifikasi. Berdasarkan studi literatur yang dilakukan, dapat disimpulkan bahwa, individu selalu melakukan komunikasi dalam berinteraksi dengan orang lain sebagai salah satu cara untuk mengurangi ketidakpastian. Salah satunya dengan melakukan beberapa strategi yaitu passive, active dan interactive strategy. Hal ini pun berlaku dalam cyber romantic relationship, sehingga teori yang dipaparkan oleh Berger \& Calabrese pada tahun 1975 (dalam Dainton \& Zelley, 2019) sesuai dan dapat diterapkan pada fenomena online dating saat ini di Indonesia. Hubungan yang terjalin pada cyber romantic relationship cenderung berlangsung cepat mulai dari proses pengenalan hingga ke tingkatan yang lebih serius atau tahap berkomitmen. Namun ketidakpastian yang terjadi pun semakin besar, dimana setiap individu memiliki kesempatan untuk menampilkan profil terbaik mereka namun sayangnya seringkali terjadi misinterpretasi bagi seseorang yang ingin melakukan hubungan jangka panjang dan berniat untuk melakukan interaksi tatap muka. Pengurangan ketidakpastian pun tidak hanya digunakan pada tahap awal perkenalan, namun juga pada tahapan saat hubungan telah berjalan yaitu relational uncertainty oleh Knobloch ketika kita mulai merasa tidak pasti akan pikiran kita sendiri, pikiran kita terhadap orang lain dan masa depan hubungan kita baik dengan teman maupun keluarga. Teori ini juga tepat untuk menggambarkan bagaimana turbulensi dapat menyebabkan ketidakpastian dalam hubungan yang sedang berjalan sehingga mengarahkan pada exit stage, yaitu kedua belah pihak memutuskan kelanjutan hubungan mereka apakah akan terus berbagi informasi personal untuk mereduksi ketidakpastian atau akan memutuskan hubungan (Jones, 2015). Terdapat dua temuan yang berbeda terkait teori relational uncertainty, dalam literatur yang dilakukan di Amerika Serikat, hubungan mantan pasangan yang masih berteman dalam social networking Facebook menemukan bahwa akhir hubungan mereka cenderung ambigu karena beberapa diantaranya mengartikan bahwa masih ada masa depan untuk hubungan romantisme mereka. Sehingga dapat diartikan bahwa ketidakpastian malah semakin meningkat, para responden merasa ketidakpastian ini akan lebih mudah dikonfirmasi apabila tidak ada peran social networking di hubungannya. Sedangkan penelitian yang dilakukan di Indonesia, ditemukan bahwa media sosial Instagram pada hubungan berpacaran dapat mereduksi ketidakpastian, karena dapat berfungsi sebagai alat kontrol pasangan seperti fitur unfollow atau block pertemanan lawan jenis yang berpotensi menimbulkan masalah.

Ditemukan bahwa tidak semua strategi pengurangan ketidakpastian dapat diterapkan pada cyber romantic relationship. Pada sebuah studi yang dilakukan di Amerika Serikat, penggunaan strategi aktif dianggap tidak pantas dilakukan oleh orang yang belum pernah melakukan pertemuan tatap muka sebelumnya. Sedangkan pada studi yang dilakukan di Indonesia, terdapat pasangan informan yang mengaku lebih nyaman melakukan strategi aktif untuk mereduksi ketidakpastian. Strategi yang selalu digunakan dan paling bisa diandalkan pada cyber romantic relationship adalah strategi pasif dan interaktif. Sedangkan penggunaan extractive strategy paling jarang digunakan karena membutuhkan kemampuan literasi yang tinggi agar tidak terjadi misinterpretasi. Kedelapan aksioma pada teori reduksi ketidakpastian dapat menjelaskan fenomena cyber romantic relationship. Namun aksioma yang paling sesuai ditemui pada online dating ialah aksioma ketiga, yaitu ketika ketidakpastian semakin tinggi dirasakan, maka perilaku mencari informasi juga semakin tinggi dilakukan. 


\section{DAFTAR PUSTAKA}

Alvin Alexander Prasetya, Joanito Kurniawan, \& Stevani. 2019. "Campaign for The Real Beauty Shampoo Dove Ditinjau Dari Terminologi Pemasaran 360 Derajat." Jurnal Lensa Mutiara Komunikasi, 3 (1): 15-35.

Anderegg, Jesse Fox \& Courtney. 2014. "Romantic Relationship Stages and Social Networking Sites: Uncertainty Reduction Strategies and Perceived Relational Norms on Facebook.” ”. Cyberpsychology, Behavior, and Social Networking 17 (11). https://doi.org/10.1089/cyber.2014.0232.

Arikunto, Suharsimi. 2010. Prosedur Penelitian: Suatu Pendekatan Prakti. Jakarta: Rineka Cipta.

Artemio Ramirez, Erin M. Sumner, Christina Fleuriet, Megan Col. 2015. "When Online Dating Partners Meet Offline: The Effect of Modality Switching on Relational Communication Between Online Daters." Journal of Computer-Mediated Communication 20: 99-114. https://doi.org/10.1111/jcc4.12101.

Christy, Firdhy Esterina. 2019. "Sepertiga Orang Indonesia Telah Menggunakan Internet Datin." Tempo.Co, 2019. https://data.tempo.co/read/485/sepertiga-orang-indonesia-telahmenggunakan-internet-dating.

Eric Fernando, Astrid Rahardaya, \& Irwansyah. 2020. "Studi Meta-Analisis Pengurangan Ketidakpastian Di Era Digital: Pencarian Informasi Di Media Sosial Sebelum Pertemuan Tatap Muka Pertama." Jurnal Lensa Mutiara Komunikasi 4: 111-13.

Ferina, Alexandra. 2019. "Pengelolaan Ketidakpastian Pada Pengguna Aplikasi Kencan Dalam Membina Hubungan Romantis (Studi Fenomenologi Pada Pengguna Tinder Di Jakarta).” Universitas Pertamina.

Griffin, Em. 2018. A First Look at Communication Theory: 10th Edition. Boston: McGraw Hill.

Indonesia, CNN. 2020. "Wabah Corona Bikin Aplikasi Kencan Online Laris Manis." CNN Indonesia, 2020. https://www.cnnindonesia.com/teknologi/20200402144747-185489624/wabah-corona-bikin-aplikasi-kencan-online-laris-manis\%0A.

Jennifer L. Gibbs, Chich-Hui Lai, Nicole B Ellison. 2015. "First Comes Love, Then Comes Google: An Investigation of Uncertainty Reduction Strategies and Self-Disclosure in Online Dating." Communication Research $38 \quad$ (1): 70-71--. https://doi.org/10.1177/0093650210377091.

Jones, Krystyle N. 2015. "The Self-Reported Reasons for Self-Disclosure and Uncertainty Reduction Strategies Used in Romantic Online Dating Relationships Compared to Face-toFace Romantic Dating Relationships." Rochester Institute of Technology.

Kamil, Ridwan. 2014. Aku, Kamu, Dan Media Sosial. Bandung: Sygma Creative Media Corp.

Keller, Kotler\&. 2012. Manajemen Pemasaran. 12th ed. Jakarta: Erlangga.

Manalu, Sa'Adatina Sa'Adatina \& S. Rouli. 2017. "Penggunaan Media Sosial Dalam Dinamika Hubungan Pacaran: Studi Terhadap Penggunaan Instagram Pada Pasangan Berpacaran." Interaksi Online 5 (4): 1-10.

Nasrullah, Rulli. 2017. Media Sosial: Perspektif Komunikasi, Budaya, Dan Sosioteknologi. Bandung: Remaja Rosdakarya. 
Neuman, W. Lawrence. 2017. Metodologi Penelitian Sosial: Pendekatan Kualitatif Dan Kuantitatif. 7th ed. Jakarta: Indeks.

Paramita, Pradnya Aisyah. 2019. "Pengurangan Ketidakpastian Pengungkapan Perasaan Pasangan Yang Terlibat Dalam Cyber Romantic Relationship (CRR)." IR-Perpustakaan Universitas Airlangga.

Sanjay, Satviki. 2020. "Data Menunjukkan Makin Banyak Anak Muda Pakai Aplikasi Kencan Buat Ngobrol Doang." Vice.Com. 2020.

Stephen W. Littlejohn, Karen A. Foss, John G. Oetzel. 2017. Theories of Human Communication. 11th ed. Belmont, CA: Thomson Wadsworth.

Warber, Jesse Fox \& Katie M. 2014. "Social Networking Sites in Romantic Relationships: Attachment, Uncertainty, and Partner Surveillance on Facebook." Cyberpsychology, Behavior, and Social Networking 17 (11). https://doi.org/10.1089/cyber.2012.0667.

Zelley, Marianne Dainton \& Elaine D. 2019. Applying Communication Theory for Professional Life: A Practical Introduction. 4th Edition. Thousand Oaks: SAGE Publications, Inc. 